\title{
NATURAL HOSTS OF MOSQUITOES IN NORTHERN ELLESMERE ISLAND*
}

\author{
Philip S. Corbet $\uparrow$ and A. E. R. Downe**
}

\begin{abstract}
Observations on blood-feeding in nature, and precipitin tests on engorged females, have been made on mosquitoes, Aedes impiger and $A$. nigripes, occurring near Lake Hazen, N.W.T. $\left(81^{\circ} 49^{\prime} \mathrm{N} ., 71^{\circ} 18^{\prime} \mathrm{W}\right.$.). Terrestrial vertebrates recorded from the area are listed. Both species of mosquitoes obtain blood in nature from musk oxen and birds (also humans); several specimens contained blood of two kinds (precipitin test determinations). Host reaction to harassment by mosquitoes is evidently a major factor determining which potential hosts are fed on successfully. On the basis of their behaviour and situation, musk oxen, and birds nesting in water-logged sites are deemed the most likely animals to provide blood. Methods for determining host preferences in the Arctic are briefly discussed.
\end{abstract}

RESUMÉ. Les Hôtes naturels des moustiques dans le nord de l'âle d'Ellesmere. Près du lac Hazen, T. du N.-O. $\left(81^{\circ} 49^{\prime}\right.$ N., $71^{\circ} 18^{\prime}$ O. $)$, les auteurs ont effectué des observations sur l'alimentation en sang et des tests a la précipitine sur des femelles gorgées d'Aedes impiger et $\boldsymbol{A}$. nigripes. On donne une liste des vertébrés terrestres mentionnés pour la région. Dans la nature, les deux espèces de moustiques soutirent du sang des boeufs musqués et des oiseaux (également des humains); plusieurs spécimens contiennent du sang des deux espèces (déterminations par les tests à la précipitine). La réaction de l'hôte au harassement par les moustiques est évidemment le facteur majeur qui détermine lequel des hôtes possibles sera attaqué avec succès. D'après leur comportement et leur situation, on estime que les boeufs musqués et les oiseaux nichés dans des sites aquatiques sont les plus susceptibles de fournir du sang. Les auteurs discutent brièvement des méthodes servant à déterminer les préférences envers les hôtes dans l'Arctique.

REZIUME. Estestvennye khoziâeva moskitov na. Severe ostrova Ėlsmir. Nablîudenîa krovososanîâ v prirodnykh uslovî́akh i pretsipitinnye reaktsii samok Aedes impiger i A. nigripes, nalitykh krov'iu, byli provedeny podle ozera Gazen $\left(81^{\circ} 49^{\prime} \mathrm{N} .71^{\circ} 18^{\prime} \mathrm{W}\right.$.). Zemnye pozvonochnye zhivotnye, vstrecharushchiesia v etol oblasti, perechisliânutsia. Oba vida moskitov sosut' krov' ovtselyka, ptifs, a takzhe cheloveka; neskol'ko ėkzemplíarov soderzhali v sebe dva vida krovi po dannym pretsipitinnol reaktsii. Reaktsiá "khozáina" na bespokorstvo prichinrâemoe moskitami, ochevidno reshaet, kotorył iz nikh predstavliâet luchshił istochnik pishchi. Na osnove ikh povedenira i mestonakhozhdenira, ovtsebyki i ptitsy, gnezdurushchie v zabolochennykh mestakh, 1âvẫ̂utsıa, povidimomu, glavnym istochnikom krov'. Metodika issledovaniîa predpochtenia moskitami "khoziaina" v Arktike kratko obsuzhdaetsia.

\section{Introduction}

$I^{N}$ N Some high arctic localities mosquitoes are abundant and seek blood actively, although natural hosts for them seem to be sporadic and scarce. To ascertain where and how such mosquitoes obtain blood is a necessary step towards understanding their adaptations to an apparently severe environment. Most contributors to this subject have noted vertebrates to which mosquitoes were attracted,

* Paper No. 26 in the program "Studies on Arctic Insects," Entomology Research Institute, Canada, Department of Agriculture in collaboration with the Defence Research Board of Canada.

† Entomology Research Institute, Canada Department of Agriculture, Ottawa, Ontario.

* Department of Biology, University of Saskatchewan, Regina, Saskatchewan. 
but not the latter's success in obtaining blood. This paper reports field observations of blood-feeding, and results of precipitin tests made on mosquitoes occurring near Hazen Camp, on the northwest shore of Lake Hazen, northern Ellesmere Island, N.W.T. $\left(81^{\circ} 49^{\prime} \mathrm{N} ., 71^{\circ} 18^{\prime} \mathrm{W}.\right)$. The collections and most of the observations were made in 1963.

The area, a sparsely vegetated treeless tundra (Savile 1964), contains many ponds, temporary and permanent, in which mosquito larvae develop in June and July. Two species of biting mosquito occur there: Aedes (Ochlerotatus) impiger Dyar (previously nearcticus Dyar) and A. (O.) nigripes (Zett.) (Oliver 1963). Both have a holarctic distribution; and at Lake Hazen some females of both species can reproduce without a bloodmeal (Corbet 1964). Savile and Oliver (1964) have listed the eighteen birds and seven mammals that inhabited the area between June and August 1962 (the mosquito flying season). These, with additional species in 1961 (D. R. Oliver, personal communication) and 1963, are as follows:

\section{BIRDS}

Gaviidae

Anatidae

Tetraonidae

Gruidae

Charadriidae

Scolopacidae

Phalaropodidae

Stercorariidae

Laridae

Strigidae

Fringillidae

Mammals

Canidae

Mustelidae

Leporidae

Cricetidae

Cervidae

Bovidae
Gavia stellata

Branta bernicla hrota

Chen hyperborea altantica

Clangula hyemalis

Somateria spectabilis

Lagopus mutus rupestris

Grus c. canadensis

Charadrius hiaticula

Arenaria i. interpres

Capella gallinago

Calidris c. canutus

Erolia bairdii

Crocethia alba

Phalaropus fulicarius

Stercorarius Iongicaudus

Larus hyperboreus

Sterna paradisaea

Nyctea scandiaca

Acanthis h. hornemanni

Calcarius l. lapponicus

Plectrophenax n. nivalis
Red-throated Loon

Brant

Snow Goose

Oldsquaw

King Eider

Rock Ptarmigan

Sandhill Crane

Ringed Plover

Ruddy Turnstone

Common Snipe

Knot

Baird's Sandpiper

Sanderling

Red Phalarope

Long-tailed Jaeger

Glaucous Gull

Arctic Tern

Snowy Owl

Hoary Redpoll

Lapland Longspur

Snow Bunting
Arctic Fox

Wolf

Ermine

Arctic Hare

Collared Lemming

Caribou

Musk ox 
Apart from man (a well-patronized host ever since small field parties began to visit the area in 1957), the more evident mammals in 1963 were musk oxen and arctic hare, both of which wander widely, often in groups. Fox, wolf, and ermine were seen occasionally, and a caribou once. The commonest birds in 1963 were ruddy turnstones, knots, and snow buntings. Red-throated loons, long-tailed jaegers, arctic terns, and oldsquaws were regularly seen.

\section{Field Observations}

Since the size and habits of a potential host often dictate whether mosquitoes can be seen feeding on it in nature, the observations which follow have only qualitative value. Unless otherwise specified, all were made in 1963. Numerical designations of habitats refer to those listed by Oliver and Corbet (1966). Weather observations given are those recorded at Hazen Camp; air temperatures having been measured in a screen. Times are Eastern Standard Time; during the observation period Solar Noon fell 8 to 12 minutes before $1200 \mathrm{~h}$ EST.

\section{RED-THROATED LOON}

On 21 July at $1750 \mathrm{~h}$, during calm, warm $\left(c .49^{\circ} \mathrm{F}\right.$.) weather, D. R. Oliver (personal communication) saw many mosquitoes congregating around a loon sitting on its nest, which was on a small mound in a tarn (No. 34). A few mosquitoes were crawling over the bird's back and wings, many were around the line of contact between bird and nest, and a dense mass covered the anal region. During a 10-minute observation none was seen to engorge. The only areas of bare skin likely to allow mosquitoes to penetrate were in the anal region. When the bird was flushed, one engorged Aedes nigripes was recovered from the edge of the nest near the anal region; it contained bird blood. Other, unfed, mosquitoes collected from the nest were $3 \mathrm{~A}$. nigripes. When the loon left the nest many mosquitoes moved to the egg. This behaviour is recorded also in a film taken by R. H. Mulvey at the same site in 1962 .

\section{KING EIDER}

This is the only wild animal on which mosquitoes have been seen engorging persistently and in numbers at Hazen Camp. Between 15 and 20 July a female remained continuously on her nest while incubating five eggs. The nest was on a small, turf-covered mound in swampy ground near No. 37.

At $2200 \mathrm{~h}$ on 15 July the weather was calm (NE breeze of less than 4 m.p.h.), clear (cloud $0 / 10$ ) and warm (c. $51^{\circ} \mathrm{F}$.), and mosquitoes (all arriving upwind) were settling on the bird at a rate of $c .8$ per minute, a value obtained during a 30-minute observation. Many alighted on the top and back of the head (especially the nape of the neck); fewer on the sides and back of the body. All probed actively but only those on the thin skin around the eyes were able to engorge (Fig. 1). Some made persistent, unsuccessful, attempts to penetrate the skin at the hinge between the upper and lower bills. Female mosquitoes collected as they probed the bird on this occasion were $25 \mathrm{~A}$. impiger and $5 \mathrm{~A}$. nigripes. This $5: 1$ proportion may be compared with the corresponding ratio of 1:2, obtained for females caught in a nearby Visual Attraction Trap (Haufe and Burgess 1960) on that day. The engorgement rate at this time was c. 12 per hour only 


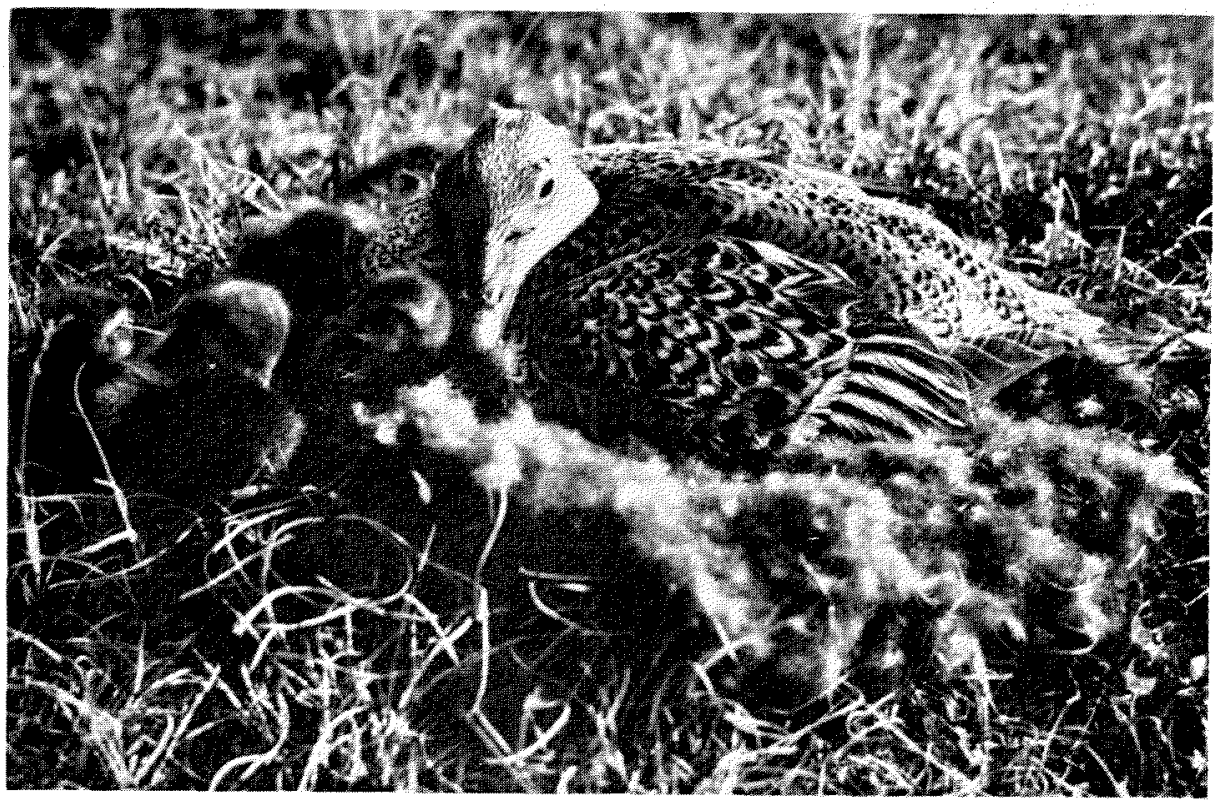

Fig. 1. King eider on nest with four newly-hatched ducklings. Mosquitoes are biting the mother duck above the eye and at the base of the bill. Hazen Camp, Northern Ellesmere Island, 20 July 1963. (Photo: P. S. Corbet)

on the eye, and nearly always on the leeward side of the bird. Occasionally the bird attempted to dislodge mosquitoes by rubbing her head against her back; this was largely ineffectual and neither displaced nor crushed feeding mosquitoes. No other similarly motivated movements were observed. A bird in this situation is indeed a "sitting duck".

Near noon on 20 July (wind from N-NE, less than 3 m.p.h.; cloud c. 4/10; c. $48^{\circ} \mathrm{F}$.) mosquitoes were arriving upwind and engorging on the eyes at a rate of c. 64 per hour (15-minute observation). Eight A. impiger and $4 A$. nigripes, removed after engorgement, all subsequently matured eggs. After 4 to 6 days (mean temperature 61-63 ${ }^{\circ}$.) the A. impiger laid 3-60 (median 39.5) eggs and the A. nigripes 23-56 (median 43.0). During the observations on 20 July the first 4 ducklings hatched and wriggled out beside the mother who remained on the nest. All were much harassed by mosquitoes. The ducklings, which were bitten only on the eyes and cere, usually shook their heads too vigorously to allow engorgement. About 30 minutes after having hatched, one duckling learnt how to catch mosquitoes from the mother's body; thereafter it consumed them actively, taking them from her head and from the other ducklings. Sometimes it even caught mosquitoes before they landed. This caused the engorgement rate to drop abruptly. Mother and young left the nest that afternoon.

\section{LONG-TAILED JAEGER}

On 20 July (when mosquitoes were actively biting a king eider nearby) two adult birds, caring for a chick on the nest, and standing nearby, were 
watched for more than 20 minutes. Opportunities for discerning mosquitoes were excellent, but none was seen to approach or settle on the adults or the chick.

\section{Arctic Fox}

On 9 July when mosquitoes were active, a fox moving slowly through camp rubbed its muzzle violently in the dust, perhaps to dislodge mosquitoes there or to relieve itching. It was not close enough for mosquitoes in attendance to be discerned.

\section{ERMINE}

On $22 \mathrm{July}$, at $1800 \mathrm{~h}$ in calm, warm weather (c. $45-50^{\circ} \mathrm{F}$.), two ermine were seen moving intermittently amongst hummocks near Hazen Camp. Mosquitoes congregated actively around the head of one when it stopped, but it frequently jerked its head and so prevented any from settling. While one ermine was inside a lemming burrow, female mosquitoes hovered over the mouth of the hole. These attempted to alight when the ermine came out but were prevented by its head-flicking. There seemed no possibility of a mosquito obtaining a blood-meal while the animals were alive and active.

\section{Arctic Hare}

Only once, on $23 \mathrm{July,}$ was a stationary hare watched closely when mosquitoes were active. It was browsing, and numerous mosquitoes were flying around its head. Many settled on its ears, and a few on the top of its head, and on its back and rump. During several minutes' observation, no mosquito remained in one place long enough to engorge. Those on the ears and head were disloged by the hare flicking its ears sideways (a frequent movement) or wiping its face with a forepaw. Mosquitoes elsewhere on the body seemed unable to penetrate the fur. It seems unlikely that mosquitoes often obtain food from a healthy, active hare.

\section{MUSK OXEN}

In early July 1958, about $12 \mathrm{~km}$. from Hazen Camp, an old bull was seen by C. R. Harington and J. Tener (C. R. Harington, personal communication) rubbing himself on a boulder, his head surrounded by a cloud of mosquitoes. The insects were mainly on the soft skin around his eyes, but they were also massing on exposed parts of the cars and on his lips. He periodically shook and rubbed his head and flicked his ears. A herd nearby was also much afflicted by mosquitoes.

On 16 July 1959, about $32 \mathrm{~km}$. from Hazen Camp, J. M. Powell (personal communication) saw a herd of 16 accompanied by a dense mass of mosquitoes which were troubling the musk oxen greatly. For about 30 minutes the musk oxen rubbed their noses and rolled on their backs, apparently in an attempt to get rid of the mosquitoes.

\section{Precipitin Tests}

Frequent sweep-net samples from low vegetation around ponds contained very few blood-engorged mosquitoes: only $14 \mathrm{~A}$. impiger and $5 \mathrm{~A}$. nigripes were obtained. These were preserved dry and the blood meals later identified using 
methods outlined previously (Downe 1960, 1962). Mosquitoes were extracted individually in $1 \mathrm{ml}$. physiological saline and subjected to preliminary tests with the following "group-specific" antisera: Group I, bovid (beef and sheep), human, feline; Group II, porcine, equine, rodent, canine; Group III, avian; Group IV, rabbit (antiserum prepared against rabbit serum in chicken). Depending upon the reactions with group-specific antisera, extracts were subjected to further tests with more specific antisera where available. Positive and negative controls were run with each series of tests. Antiserum used to detect bovid feedings was shown to cross-react with serum proteins of Cervidae (deer, moose etc.). Tests recorded as negative gave no benzidine test. Results are given in Table 1; values in brackets record the number of the total in each category that were multiple-feeds. The A. impiger (collected 11-23 July) came mainly from near ponds No. 2 and 26; the A. nigripes (collected 15-31 July) came mainly from No. 2. In addition, $1 \mathrm{~A}$. impiger was taken inside a hut; it had fed on human and rodent (possibly the lemming held captive in the hut).

Table I. Blood meals of mosquitoes near Hazen Camp.

\begin{tabular}{lcccccc}
\hline Species & Bovid & Bird & Human & Unidentified & Multiple & $\begin{array}{c}\text { Totals } \\
\text { examined }\end{array}$ \\
\hline Aedes impiger & $8(2)^{\mathbf{1}}$ & $5(3)$ & $3(1)$ & $2(2)$ & 4 & 14 \\
\hline A. nigripes & 1 & $2(1)$ & $2(1)$ & 1 & 1 & 5 \\
\hline
\end{tabular}

IValues in brackets show the number of the preceding total that were multiple feeds.

\section{Discussion}

In West Greenland, near Isersiutilik ( $64^{\circ} 40^{\prime} \mathrm{N}$., $51^{\circ} 20^{\prime} \mathrm{W}$.), Aedes nigripes has been seen attacking the eyelids of young redpolls and massing around the ears of arctic hare; both hare and reindeer there reputedly seek higher land in summer to escape from mosquitoes (Longstaff 1932). This mosquito attacks reindeer, living and dead, on the Taimyr Peninsula $\left(75-77^{\circ} \mathrm{N}\right.$., $105-115^{\circ} \mathrm{E}$.) (Kiseleva 1936). At Eureka, N.W.T. $\left(80^{\circ} 00^{\prime}\right.$ N., $85^{\circ} 56^{\prime}$ W.), where both species of Hazen mosquito occur, hare and musk oxen are said to be much molested by them (Bruggemann 1958). And in Northeast Greenland, where A. nigripes exists, musk oxen are attacked severely by mosquitoes (Mecking, in Nordenskjöld and Mecking 1928). There have been no reports of mosquitoes actually engorging on wild animals in these areas.

Results presented here emphasize the importance of confirming circumstantial evidence by observation of actual engorgement or by blood meal identification. Although mosquitoes may congregate around small, active mammals, such as hare, fox, ermine, and lemming, it is unlikely that appreciable numbers obtain blood while the animals are alive and awake. On the other hand, vertebrates that are slow-moving (bovids) or immobile for extended periods (incubating birds) are on these counts more likely to be attacked successfully. Observations at Hazen Camp, like those on allied mosquitoes in Scandinavia (Ardö 1958), show that mosquitoes do obtain blood from these two sources.

Musk oxen, being exceptionally large, slow-moving and dark, and commonly travelling in groups, would seem to be among the easiest hosts for mosquitoes 
to locate from a distance over the tundra if warmth (Brown 1951) or surfacearea (Downe 1960, 1962) of host affects their orientation. It should be remembered, however, that musk oxen respond vigorously to harassment by mosquitoes. When the number of mosquitoes per musk ox is high, it is possible that (as Glasgow, 1963, has suggested for large animals attacked by tsetse) the musk ox may react so much that it effectively resists being fed on. Whether or not this extreme condition is ever reached, we may reasonably suppose that, as the relative density of mosquitoes increases, a progressively smaller proportion of them will obtain blood. Thus will a density-dependent restriction be imposed upon mosquito fecundity. By the same token vigorous host reaction may also be expected to increase the proportion of multiple-feeds, which at Hazen Camp was fairly high (Table I). There may indeed be a relationship between the reaction of a host and the number of times it features in multiple- but not single-feed categories (Edman and Downe 1964).

Incubating birds are differently placed. Once mosquitoes have located them, such birds are particularly vulnerable, since they must remain immobile to escape detection by predators. Those nesting in or near ponds will presumably fare worst because the nest is typically on a prominence from which warm air can flow downwind. Birds nesting in sheltered depressions are probably less easily located by mosquitoes.

The small number of engorged specimens obtained in sweep-net catches merits comment. It may have resulted from a real scarcity of blood-fed females, or from their having had an aggregate distribution not adequately covered by our sampling. Certainly the second possibility is likely. Freshly-engorged females watched in the field fly only a few metres from their host and then settle, probably remaining inactive there until nearly ready to oviposit (Shemanchuk, Downe, and Burgess 1963). Thus the blood-fed females in field collections are likely either to be scarce or else, as Muirhead-Thomson (1951) and others have remarked, to be heavily weighted in favour of the nearest available host. The results of precipitin tests, especially in arctic areas where natural hosts are widely dispersed, will accordingly depend on the sampling area chosen, and so could be misleading if used for a general statement of food preferences.

Fortunately a high arctic locality, with its small and easily observed vertebrate fauna, is well-suited for observations of mosquito feeding-success in nature. Mosquitoes are probably unselective in such areas; once attracted, their success in obtaining blood will depend on the behaviour of the potential host, a matter to be ascertained only by field observation. When a host's suitability has been assessed in this way, intensive sweep-net collections within a radius of $50 \mathrm{~m}$. around it should yield enough blood-fed females to confirm the observer's suspicions and to indicate the species of mosquito involved. In such localities this approach should reveal what kind of vertebrates supply most blood, and why. Such information could form the basis of prediction in other areas where the composition of the vertebrate fauna was known.

Field observations of this kind may also throw some light on the existence of attractive substances released from certain parts of the host body, such as that detected for blackflies in the common loon (Lowther and Wood 1964) and certain ducks (Fallis and Smith 1964). The observation reported here of mosquitoes massing around the anal region of a loon may offer a case in point, 
although this may only have expressed a response to localized warmth. Either kind of response, it may be noted, might serve to guide mosquitoes to penetrable parts of the body.

After feeding, female mosquitoes have an aggregate distribution determined by the locations of hosts. When their ovaries have matured it is assumed that dispersal, and therefore a certain amount of redistribution, takes place before the mosquitoes again aggregate at oviposition sites. This suggests that the best place to collect samples for ascertaining overall host preferences might be the oviposition site, for by that time some of the earlier host-bias should have been obliterated by mixing. Whether or not the remnant of the blood-meal would still be recognizable at this late stage needs to be determined. If it were, consistently, the method might have value in another way also: the relative proportions of autogenous and anautogenous females among those gravid could be determined. In the Ottawa area $\left(45^{\circ} \mathrm{N}\right.$.), under field conditions, most bloodmeals of Aedes can be detected by the precipitin test 4 days after feeding (Downe 1960). At Hazen Camp, in nature during July, females Aedes can become gravid 6 to 8 days after feeding (Corbet 1965), but possibly digestion of blood proceeds more slowly than in the Ottawa area. This point is being investigated.

\section{Acknowledgments}

We thank Mr. W. Forrest who collected some of the field samples; and also those persons (mentioned by name in the text) who allowed us to cite their unpublished records.

\section{References}

Ardö, P., 1958. On the feeding habits of the Scandinavian mosquitoes. Opusc. Entomol. 23:171-91.

Brown, A. W. A., 1951. Studies of the responses of the female Aedes mosquito. Part IV. Field experiments on Canadian species. Bull. Entomol. Res. 42:575-82.

Bruggemann, P. F., 1958. Insects and environments of the high arctic. Proc. X Int. Congr. Entomol., Montreal (1956) 1:695-702.

Corbet, P. S., 1964. Autogeny and oviposition in arctic mosquitoes. Nature, 203:668.

, 1965. Reproduction in mosquitoes of the high arctic. Proc. XII Int. Congr. Entomol., Lond. (1964) 817-18.

Downe, A. E. R., 1960. Blood-meal sources and notes on host preferences of some Aedes mosquitoes (Diptera: Culicidae). Can. J. Zool. 38:689-99.

(Diptera: Culicidae). Can. J. Zool. 40:725-32.

Edman, J. D. and A. E. R. Downe, 1964. Host-blood sources and multiple-feeding habits of mosquitoes in Kansas. Mosquito News 24:154-60.

Fallis, A. M. and S. M. Smith, 1964. Ether extracts from birds and $\mathrm{CO}_{2}$ as attractants for some ornithophilic simuliids. Can. J. Zool. 42:723-30.

Glasgow, J. P., 1963. The distribution and abundance of tsetse. London: Pergamon Press.

Haufe, W. O. and L. Burgess, 1960. Design and efficiency of insect traps based on visual response to patterns. Can. Ent. 92:124-40.

Kiseleva, E. F., 1936. [Zur Mückenfauna des Westlichen Teils der Taimyrhalbinsel.] (In Russian; German summary.) Trav. Inst. Sci. Biol. Tomsk 2:132-35. (Seen in Rev. Appl. Entomol. (B) 26:104.) 
Longstaff, T. G., 1932. An ecological reconnaissance in west Greenland. J. Anim. Ecol. $1: 119-42$.

Lowther, J. K. and D. M. Wood, 1964. Specificity of a black fly, Simulium euryadminiculum Davies, towards its host, the common loon. Can. Entomol. 96:911-13.

Muirhead-Thomson, R. C., 1951. Mosquito behaviour in relation to malaria transmission and control in the tropics. London: Edward Arnold.

Nordenskjöld, N. O. G. and L. Mecking, 1928. Geography of the polar regions. Amer. Geogr. Soc. Spec. Publ. No. 8. 1-116 pp.

Oliver, D. R., 1963. Entomological studies in the Lake Hazen area, Ellesmere Island, including species lists of Arachnida, Collembola and Insecta. Arctic 16:175-80.

and P. S. Corbet, 1966. Aquatic habitats in a high arctic locality: the Hazen Camp area, Ellesmere Island, N.W.T. Def. Res. Board, Department of National Defence, Ottawa (in press).

Savile, D. B. O., 1964. General ecology and vascular plants of the Hazen Camp area. Arctic 17:237-58.

and D. R. Oliver, 1964. Bird and mammal observations at Hazen Camp, northern Ellesmere Island, in 1962. Can. Field-Nat. 78:1-7.

Shemanchuk, J. A., A. E. R. Downe and L. Burgess, 1963. Hosts of mosquitoes (Diptera: Culicidae) from the irrigated areas of Alberta. Mosquito News 23:336-41. 